\title{
ANALISIS KUALITAS MANAJER PROYEK TERHADAP PELAKSANAAN PROYEK KONSTRUKSI (STUDI KASUS : DI DENPASAR DAN BADUNG)
}

\author{
I Gde Eka Dharsika $^{1}$, IN.Budiartha ${ }^{2}$, I W.Yansen ${ }^{2}$
}

\begin{abstract}
Abstrak : Proyek konstruksi yang bermasalah dalam pelaksanaan pekerjaan diakibatkan oleh adanya perpanjangan waktu kerja dan kenaikan biaya kerja. Manajemen proyek yang memiliki kemampuan terbatas turut memberi kontribusi terhadap penurunan kualitas kerja proyek. Kualitas manajer proyek memiliki peranan penting untuk kelancaran suatu proyek konstruksi. Dedikasi dalam profesi ini menuntut manajer proyek untuk melaksanakan pekerjaan berjalan sesuai dengan rencana. Menganalisa kualitas manajer proyek terhadap pelaksanaan proyek konstruksi merupakan salah satu cara untuk mengukur kualitas suatu proyek. Diperlukan suatu cara pengukuran yang tepat untuk dapat memberikan penilaian akurat mengenai kualitas manajer proyek yang cakap dan handal. Penelitian ini bertujuan untuk mendapatkan faktor-faktor yang mempengaruhi kualitas manajer proyek konstruksi dan untuk mengetahui pengaruh kualitas manajer proyek terhadap pelaksanaan proyek konstruksi. Penelitian menggunakan sampel sebanyak 45 responden dari beberapa proyek konstruksi di daerah Badung dan Denpasar selama periode tahun 2007 2012. Metode yang digunakan dalam penelitian ini adalah metode analisis regresi linier berganda dengan melakukan pengujian terhadap F-test, dan t-test. Ditemukan 8 (delapan) faktor dominan yang memiliki nilai eigen values $>1$. Secara berurutan, faktor yang telah diberi nama tersebut adalah pengalaman $41,63 \%$, pendidikan $9,278 \%$, pengetahuan $7,240 \%$, kemampuan $5,088 \%$, karakter $4,047 \%$, jaringan $3,843 \%$, hubungan komunikasi $3,550 \%$, percaya diri 3,357\%. Pengaruh kualitas manajer proyek terhadap biaya proyek sebesar 51,9\%, terhadap mutu proyek sebesar $43,1 \%$, terhadap waktu proyek, dengan nilai 57,9\%. Hasil penelitian ini membuktikan bahwa adanya pengaruh kuat antara kualitas manajer proyek konstruksi berpengaruh terhadap pelaksanaan proyek konstruksi.
\end{abstract}

Kata Kunci : Kualitas, manajer, proyek, analisis faktor

\section{ANALYSIS OF PROJECT MANAGER QUALITY FOR IMPLEMENTING PROJECT CONSTRUCTION}

\begin{abstract}
Problems in construction projects caused by the extension of working time and an increase in labor costs. A limited ability of project management contribute to the decline in the quality of project work. The quality of project manager has an important role to smooth a construction project. Dedication in this profession requires project managers to carry out the work going according to plan. Analyzing the quality of the project manager for the implementation of construction projectsis one wayto measure the quality of a project. It needs a right measurements way to providean accurate assessment of qualified and reliable project managers. This study aimed to obtain and analyze the factors that affect the quality of the project manager and its to construction projects. This used a sample of 45 respondents from several construction projects in the area of Badung and Denpasar during the period 2007-2012. The method used in this study is the method of multiple linear regression analysis by testing for the F-test and t-test. The results found 8 dominant factor that has a value eigen values> 1. Sequentially, the factors that have been named are experience $41.63 \%$, education $9.278 \%$, knowledge $7.240 \%$, ability $5.088 \%$, character $4.047 \%$, network $3.843 \%$, relationship communication $3.550 \%$, confidence $3.357 \%$. Influence the quality of the project manager on the performance fee of $51.9 \%$, against $43.1 \%$ for quality performance, on-time performance, with a value of $57.9 \%$. The results of this study prove that the powerful influence between the quality of the construction project manager to the implementation of construction projects.
\end{abstract}

Keywords: Quality, manager, project, factor analysis

\footnotetext{
${ }^{1}$ Mahasiswa Program Magister Teknik Sipil, Fakultas Teknik, Universitas Udayana Denpasar

${ }^{2}$ Staf Pengajar Program Studi Magister Teknik Sipil, Fakultas Teknik, Universitas Udayana Denpasar
} 


\section{PENDAHULUAN}

Kualitas manajer proyek memegang peranan penting dalam kelancaran suatu proyek konstruksi. Dedikasi dan konsistensinya dalam profesi ini menuntutnya untuk mengendalikan pekerjaan agar tetap berjalan sesuai dengan rencana. Manajemen proyek menjadi bekal utama untuk menyiapkan pekerjaan proyek hingga pekerjaan diserahkan pada pemilik. Pekerjaan proyek dimulai dari perencanaan dengan para konsultan, klarifikasi bersama rekan kerja, negosiasi, pelaksanaan proyek, hingga pertanggungjawaban di akhir pekerjaan.

Selama ini sering ditemui adanya keterlambatan pekerjaan proyek yang menyebabkan terjadinya kerugian. Berbagai persoalan yang terjadi karena manajemen waktu yang kurang baik. Kemampuan manajer proyek dalam mengantisipasi adanya waktu kerja yang diliburkan secara nasional masih cukup lemah. Prediksi yang disiapkan masih belum cukup mampu untuk mengatasi kekurangan sumber daya manusia pada waktu tertentu. Libur hari raya yang terjadi dalam waktu yang bersamaan dan cukup panjang telah memberi kontribusi besar pada sisi waktu pekerjaan proyek.

Peningkatan biaya juga sering terjadi pada saat proyek telah berjalan. Kebutuhan dana untuk pengadaan material di pasaran yang harganya sering meningkat mengikuti kebijakan pemerintah. Kemampuan manajer proyek yang terbatas dalam memilih suplier untuk dapat memberi penawaran harga yang terbaik akan memberi dampak pada peningkatan biaya. Negosiasi yang masih lemah dalam berbagai penawaran harga material, tenaga kerja, lingkungan di sekitar proyek turut memberi kontribusi besar penyebab biaya menjadi membengkak.

Perubahan yang terjadi pada biaya dan waktu akan berpengaruh pada kualitas proyek. Pengguna jasa selaku pemilik proyek telah memiliki ukuran kualitas yang telah disepakati dengan penyedia jasa. Manajer proyek harus memahami mengenai manajemen proyek seutuhnya, baik hal teknis maupun administrasi terkait pelaksanaan di lapangan. Manajer proyek paham dengan segala kebutuhan dalam melaksanakan proyek, tanpa harus mengetahui penguasaan pekerjaan secara total. Manajer Proyek juga dapat berperan sebagai seorang manajer sumber daya manusia, manajer keuangan, dan manajer komunikasi dalam lingkup proyeknya. Berdasarkan paparan tersebut maka tujuan dari penelitian ini adalah untuk menganalisis faktor-faktor dari kualitas manajer proyek yang berpengaruh terhadap proyek konstruksi dan mengetahui hubungan kualitas manajer proyek dan pengaruhnya terhadap pelaksanaan proyek konstruksi.

\section{SISTEM MANAJEMEN MUTU}

Teori dari ISO 8402 quality vocabulary, mengemukakan bahwa kualitas berarti semua aktivitas dari fungsi manajeman secara keseluruhan yang menentukan kebijaksanaan kualitas, tujuantujuan dan tanggungjawab serta mengimplementasikan melalui alat-alat seperti: perencanaan kualitas, pengendalian kualitas, jaminan kualitas, dan peningkatan kualitas. ISO menegaskan pada standar kualitas yang dikeluarkan melalui ISO 9000 tentang Implementasi Sistem Manajemen Kualitas kemudian disusul dengan ISO 9001, 9002, 9003 tentang quality management dan ISO 9004 tentang Quality Management and Quality System Guidelines.

Edward Deming, mengemukakan kualitas berarti pemecahan masalah untuk mencapai penyempurnaan terus menerus. Seluruh komponen yang terlibat dalam pencapaian kualitas merupakan suatu community yang saling memberi dukungan (Suardi, 2003) proses ini sering disebut siklus Deming yaitu Plan, Do, Check, dan Action.

Philip B. Croby mengemukakan kualitas berarti kesesuaian terhadap persyaratan. Crosby memandang masalah kualitas dengan berbagi 4 langkah yaitu Conformance, Prevention of Defects, Zero Defect dan Performance Measurement. Empat langkah yang dikemukakan oleh Philip B. Crosby merupakan rangkaian Top-Down. Untuk mencapai kualitas yang diharapkan konsumen. Kebutuhan dan keinginan konsumen harus dikenali terlebih dahulu sebelum melakukan proses produksi, didalam proses harus menghindari terjadinya kesalahan yang akan meningkatkan biaya dan waktu produksi. Pencapaian bebas cacat adalah mutlak karena setiap cacat yang terjadi berarti biaya. Dari proses ini memerlukan tolak ukur yang digunakan sebagai pedoman dan secara terus menerus ukuran kualitas akan meningkat. Joseph M. Juran mengemukakan kualitas berarti kesesuaian dengan penggunaan berorientasi pada pemenuhan harapan konsumen. Konsep Juran mempengaruhi perjalanan kualitas yang dijadikan sebagai tolok ukur pada dunia industri.

PMI (Project Management Institue) mengemukakan dalam Project Management Body 
of Knowledge khususnya didalam pelaksanaan pekerjaan proyek pembangunan berbeda dibandingkan dengan konsep Trilogi Juran yaitu sudut pandang Quality Improvement dengan Quality Assurance yang dirasa lebih tepat digunakan pada industri konstruksi sehingga 3 prinsip kunci yang dikemukakan PMI adalah Quality Planning, Quality Assurance dan Quality Control.

Mendapatkan standar kinerja mutu yang baik dapat dilakukan dengan mengadopsi beberapa sistem perencanaan dan pengendalian mutu seperti uraian berikut ini (Husen, 2009):

1. Menerapkan Sistem Manajeman Mutu ISO 9000 dengan menjalankan prosedur sebagai bagian dari keseluruhan sistem untuk mendapatkan produk akhir yang sesuai dengan yang direncanakan. Prinsip-prinsip dasar yang dilakukan adalah membuat dan menulis perencanaan, melaksanakan dan mengendalikan sesuai dengan rencana serta mencatat apa yang telah dilakukan.

2. Untuk melengkapi persyaratan sistem mutu diatas sehingga didapat mutu terbaik terhadap standar produk akhir, dilakukan dengan cara membuat gambar kerja yang detail dan akurat, lalu nmembuat spesifikasi umum dan teknis terhadap pekerjaan dan material yang digunakan.

3. Untuk pengendalian selama proyek, jadwal pengiriman material harus tepat waktu, proses penyimpanan material aman dan terlindung, selain itu dibuatkan format standar prosedur operasional mengikuti spesifikasi yang telah ditetapkan dalam penggunaan materialnya

4. Melengkapi pengendalian kinerja mutu dapat dilakukan dengan membuat prosedur dan instruksi kerja dari total quality control yaitu dengan melakukan kegiatan perencanaan (plan), pelaksanaan (do), pemeriksaan (check), tindakan koreksi (corrective action).

Manajer dapat diklasifikasikan dalam dua cara yaitu : menurut tingkatnya dalam organisasi, yaitu manajer lini-pertama, manajer menengah, serta manajer puncak dan menurut rentang kegiatan organisasi yang ada di bawah tanggung jawabnya, yaitu yang disebut manajer fungsional dan manajer umum (Stoner dan Wankel, 1986)

Berikut ini adalah tingkatan manajer mulai dari bawah ke atas :

Manajemen lini pertama (first-line management), dikenal pula dengan istilah manajemen operasional, merupakan manajemen tingkatan paling rendah yang bertugas memimpin dan mengawasi karyawan non-manajerial yang terlibat dalam proses produksi. Mereka sering disebut penyelia (supervisor), manajer shift, manajer area, manajer kantor, manajer departemen, atau mandor (foreman).

1. Manajemen tingkat menengah (middle management), mencakup semua manajemen yang berada diantara manajemen lini pertama dan manajemen puncak dan bertugas sebagai penghubung antara keduanya. Jabatan yang termasuk manajer menengah diantaranya kepala bagian, pemimpin proyek, manajer pabrik, atau manajer divisi.

2. Manajemen puncak (top management), dikenal pula dengan istilah executive officer. Bertugas merencanakan kegiatan dan strategi perusahaan secara umum dan mengarahkan jalannya perusahaan. Contoh top manajemen adalah CEO (Chief Executive Officer), CIO (Chief Information Officer), dan CFO (Chief Financial Officer).

Meskipun demikian, tidak semua organisasi dapat menyelesaikan pekerjaannya dengan menggunakan bentuk piramida tradisional ini. Misalnya pada organisasi yang lebih fleksibel dan sederhana, dengan pekerjaan yang dilakukan oleh tim karyawan yang selalu berubah, berpindah dari satu proyek ke proyek lainnya sesuai dengan permintaan pekerjaan.

Manajer Fungsional bertanggungjawab atas hanya satu kegiatan organisasi, seperti produksi, pemasaran, penjualan, atau keuangan. Orang-orang dan kegiatan-kegiatan yang dikepalai oleh seorang manajer fungsional dipersatukan oleh seperangkat kegiatan yang sama.

Manajer umum mengatur sebuah unit yang kompleks, seperti sebuah perusahaan, anak perusahaan, atau sebuah divisi yang beroperasi mandiri. Manajer umum bertanggungjawab atas semua kegiatan unit tersebut, seperti produksi, pemasaran, penjualan, dan keuangan.

Manajer proyek merupakan individu atau kelompok yang bertanggung jawab untuk memimpin suatu organisasi proyek. Manajer proyek merupakan pribadi yang cakap dalam berbagai disiplin ilmu yang terkait dengan dasar ilmu manajemen proyek, seperti ekonomi keuangan, sumber daya manusia, hukum kontrak konstruksi, maupun berbagai hal teknis lainnya.

Proyek Konstruksi adalah suatu rangkaian kegiatan yang hanya satu kali dilaksanakan dan umumnya berjangka pendek. Dalam rangkaian kegiatan tersebut, ada suatu proses yang mengelola sumber daya proyek menjadi suatu kegiatan yang berupa bangunan. Proses yang terjadi dalam rangkaian kegiatan ini tentunya melibatkan pihakpihak yang terkait, baik secara langsung maupun tidak langsung.

Proyek Konstruksi mempunyai 3 (tiga) karakteristik yang dapat dipandang secara tiga dimensi (Ervianto, 2003) yaitu : 
1. Bersifat Unik

Proyek konstruksi tidak pernah terjadi rangkaian kegiatan yang sama persis, proyek bersifat sementara dan selalu terlibat grup pekerja yang berbeda-beda

2. Membutuhkan Sumber Daya

Proyek Konstruksi membutuhkan sumber daya, yaitu pekerja, uang, mesin, metoda dan material. Pengorganisasian semua sumber daya dilakukan oleh manajer proyek.

3. Organisasi

Setiap organisasi mempunyai keragaman tujuan dimana didalamnya terlibat sejumlah individu dengan keahlian yang bervariasi, perbedaan ketertarikan, kepribadian yang bervariasi, dan ketidakpastian. Manajer Proyek harus menyatukan visi menjadi satu tujuan yang ditetapkan oleh organisasi

Penelitian tentang analisa kinerja mandor dalam menerapkan manajemen kualitas penah dilakukan oleh Sukaratha (2006), yang menemukan bahwa adanya korelasi yang sangat rendah. Penelitian yang mengacu pada tingkat pendidikan, pengalaman, motivasi dan disiplin mandor ini, memberi gambaran bahwa semua item tersebut tidak secara signifikan dapat menunjang kemampuan mandor dalam menerapkan manajemen kualitas. Ternyata skor yang baik, pendidikan $94 \%$; pengalaman $86 \%$; motivasi $67 \%$; disiplin 89\%; belum cukup baik menunjang kemampuan mandor menerapkan manajemen kualitas.

Penelitian serupa juga dilakukan oleh Zacky (2001), tentang pengaruh kualitas manajemen proyek terhadap kinerja waktu pelaksanaan proyek konstruksi di Jabotabek. Penelitiannya membuktikan secara kualitatif analisa kualitas manajer proyek, baik itu pendidikan, pengalaman, pengetahuan dan kemampuan, serta karakter yang yang baik akan meningkatkan kinerja waktu proyek. Hal ini tampak dari analisa statistik yang menyatakan hubungan korelasi positif yang kuat antara variabel analisa kualitas manajer proyek konstruksi.

Penelitian - penelitian tersebut menyarankan untuk manajemen proyek (kontraktor, konsultan) lebih banyak memberikan bimbingan/ pelatihan manajemen kualitas seperti cara-cara menerapkan perencanaan, pemeriksaan, dan jaminan kepada mandor/manajer proyek yang masih kurang memahami. Hasil penelitian ini akan dijadikan salah satu referensi bagi penelitian kinerja manajer proyek.

\section{METODE}

Pendekatan yang dilakukan dalam penlitian ini untuk mempelajari dan mengetahui faktorfaktor dari seorang manajer proyek yang mempengaruhi kinerjanya dalam melaksanakan kewajibannya sebagai penanggungjawab pelaksanaan proyek konstruksi.

\section{Jumlah sampel dan Teknik sampling}

Teknik pengambilan sampel/ responden dilakukan berdasarkan metode purposive sampling, yaitu teknik sampling yang digunakan peneliti berdasarkan atas kemampuan dan pengetahuan serta pertimbangan tertentu dalam menentukan responden yang diyakini mampu memberikan jawaban pada kuesioner sesuai dengan topik penelitian (Sugiyono, 2004).

Pemilihan lokasi penelitian berada di wilayah area Kota Denpasar dan Kabupaten Badung. Proyek yang dipilih merupakan proyek yang memiliki nilai diatas Rp 1.000.000.000,00. Subyek penelitian merupakan rekan kerja dari manajer proyek.

\section{Analisis Data}

Analisis data yang dilakukan meliputi:

1. Uji Validasi: dilakukan untuk mendapatkan nilai validitasnya. Uji signifikansi dilakukan dengan membandingkan nilai $r$ hitung dengan $\mathrm{r}$ tabel untuk degree of freedom $(\mathrm{df})=\mathrm{n}-2$ dan alpha $=0,05$. Dengan menggunakan program SPSS dapat melihat tampilan output Cronbach Alpha pada kolom Correlated Item - Total Correlation. Bandingkan nilai Correlated Item - Total Correlation dengan hasil hitungan $r$ tabel, jika $r$ hitung lebih besar dari $r$ tabel dan nilai positif maka butir pertanyaan atau indikator dinyatakan valid.

2. Uji Reliabilitas: untuk uji reliabilitasnya digunakan alpha Cronbach, yang merupakan teknik yang tepat untuk menentukan suatu instrumen reliabel atau tidak reliabel. Kriteria suatu instrumen dikatakan reliabel dengan menggunakan teknik ini, bila koefisien realibilitasnya $\left(\mathrm{r}_{11}\right)>0,6$.

3. Analisis Korelasi: dilakukan untuk mengetahui hubungan antara faktor-faktor dalam lelang terhadap partisipasi dan perolehan proyek.Analisis Korelasi pada penelitian ini dilakukan untuk mengukur kekuatan hubungan antar setiap variabel. Analisa korelasi menggunakan Measures of Sampling Adequacy(MSA). Dengan menggunakan program SPSS, perhitungan metode ini yang ditampilkan pada tabel Antiimage Correlation, determinant matrik korelasi semuanya menunjukkan nilai selain 0 (nol). Tabel tersebut menyimpulkan bahwa analisis faktor dapat dilanjutkan.

4. Analisis Faktor digunakan untuk mendapatkan faktor-faktor dari kualitas manajer proyek. Analisis faktor dilakukan dengan metode Principal Component Analysis 
dan metode rotasi Varimax dengan criteria dari Kaiser yang mengambil komponen yang mempunyai eigen values $>1$.

5. Analisis Regresi Linier Berganda dilakukan dilakukan terhadap semua faktor yang akan menjadi variabel penentu dalam persamaan regresi. Analisis ini dilakukan untuk mengetahui pengaruh faktor-faktor kualitas manajer proyek terhadap pelaksanaan proyek konstruksi.

\section{HASIL DAN PEMBAHASAN}

Uji signifikansi menunjukkan bahwa $r$ tabel adalah 0,325 Dari hasil output tersebut didapat $r$ hitung lebih besar dari $r$ tabel dan nilai positif maka butir pertanyaan atau indikator dinyatakan valid. Uji reliabilitas menghasilkan output nilai Cronbach's Alpha sudah > 0,60 yaitu sebesar 0,959 maka dari itu pertanyaan kuesioner ini dinyatakan reliabel. Dari analisis faktor variabel bebas yang nilai eigen values $>1$ telah menghasilkan 8 komponen atau faktor seperti terlihat pada Total Variance Explained maupun rotated Component Matrix.

Tabel 1. Hasil Analisa Faktor

\begin{tabular}{|c|c|c|c|}
\hline $\mathbf{F}$ & $\mathbf{V}$ & $\begin{array}{l}\text { Uraian Kualitas } \\
\text { Manajer Proyek }\end{array}$ & $\mathbf{r}$ \\
\hline \multirow{10}{*}{1} & P3 & $\begin{array}{l}\text { Pendidikan non formal } \\
\text { teknik sipil: Manajemen } \\
\text { Konstruksi Profesional }\end{array}$ & 0.751 \\
\hline & P11 & $\begin{array}{l}\text { Pernah bekerja pada } \\
\text { beberapa proyek } \\
\text { konstruksi }\end{array}$ & 0.776 \\
\hline & P13 & $\begin{array}{l}\text { Pernah bekerja pada } \\
\text { perusahaan non } \\
\text { konstruksi }\end{array}$ & 0.562 \\
\hline & P17 & $\begin{array}{l}\text { Pernah bekerja sebagai } \\
\text { manajer proyek } \\
\text { konstruksi }\end{array}$ & 0.614 \\
\hline & P18 & $\begin{array}{l}\text { Pernah bekerja di proyek } \\
\text { konstruksi sebagai } \\
\text { konsultan }\end{array}$ & 0.638 \\
\hline & P21 & $\begin{array}{l}\text { Pernah dan atau masih } \\
\text { aktif sebagai pengajar } \\
\text { manajemen proyek }\end{array}$ & 0.566 \\
\hline & P22 & $\begin{array}{l}\text { Pernah menjadi } \\
\text { pemimpin proyek }\end{array}$ & 0.665 \\
\hline & P24 & $\begin{array}{l}\text { Pernah bekerja di proyek } \\
\text { dalam keadaan dibawah } \\
\text { tekanan }\end{array}$ & 0.661 \\
\hline & p30 & $\begin{array}{l}\text { Pengetahuan tentang } \\
\text { material/bahan } \\
\text { Konstruksi }\end{array}$ & 0.751 \\
\hline & p33 & $\begin{array}{l}\text { Pengetahuan tentang } \\
\text { sistem kerja Mechanical, } \\
\text { Electrical dan Plumbing }\end{array}$ & 0.515 \\
\hline
\end{tabular}

\begin{tabular}{|c|c|c|c|}
\hline $\mathbf{F}$ & $\mathbf{V}$ & $\begin{array}{c}\text { Uraian Kualitas } \\
\text { Manajer Proyek }\end{array}$ & $\mathbf{r}$ \\
\hline \multirow{8}{*}{2} & $\mathrm{P} 1$ & $\begin{array}{l}\text { Pendidikan formal } \\
\text { teknik sipil }\end{array}$ & 0.866 \\
\hline & $\mathrm{P} 2$ & $\begin{array}{l}\text { Pendidikan formal bukan } \\
\text { teknik sipil }\end{array}$ & 0.856 \\
\hline & P5 & $\begin{array}{l}\text { Pendidikan non formal } \\
\text { teknik sipil: } \\
\text { Kursus/pelatihan } \\
\text { Manajemen Konstruksi }\end{array}$ & 0.843 \\
\hline & $\mathrm{P} 10$ & Berani mengambil resiko & 0.703 \\
\hline & $\mathrm{P} 14$ & $\begin{array}{l}\text { Pernah dan atau sedang } \\
\text { menjadi pengajar di } \\
\text { lembaga pendidikan }\end{array}$ & 0.579 \\
\hline & $\mathrm{P} 20$ & $\begin{array}{l}\text { Pernah mengikuti } \\
\text { pelatihan kepemimpinan }\end{array}$ & 0.565 \\
\hline & $\mathrm{p} 25$ & $\begin{array}{l}\text { Pernah mengikuti kursus } \\
\text { atau seminar dari } \\
\text { lembaga ahli manajemen } \\
\text { proyek }\end{array}$ & 0.683 \\
\hline & P27 & $\begin{array}{l}\text { Pengetahuan tentang } \\
\text { manajemen waktu }\end{array}$ & 0.46 \\
\hline \multirow{6}{*}{3} & P28 & $\begin{array}{l}\text { Pengetahuan tentang } \\
\text { manajemen kualitas }\end{array}$ & 0.56 \\
\hline & P31 & $\begin{array}{l}\text { Pengetahuan tentang } \\
\text { administrasi proyek }\end{array}$ & 0.713 \\
\hline & P34 & $\begin{array}{l}\text { Pengetahuan tentang } \\
\text { manajemen proyek } \\
\text { konstruksi }\end{array}$ & 0.735 \\
\hline & P35 & $\begin{array}{l}\text { Pengetahuan teknis } \\
\text { organisasi proyek } \\
\text { konstruksi }\end{array}$ & 0.785 \\
\hline & P36 & $\begin{array}{l}\text { Pengetahuan tentang } \\
\text { material/bahan } \\
\text { Konstruksi }\end{array}$ & 0.824 \\
\hline & P37 & $\begin{array}{l}\text { Pengetahuan tentang } \\
\text { sistem perijinan } \\
\text { bangunan }\end{array}$ & 0.806 \\
\hline \multirow{3}{*}{4} & $\mathrm{P} 12$ & $\begin{array}{l}\text { Pernah mengurus } \\
\text { manajemen keuangan } \\
\text { proyek }\end{array}$ & 0.653 \\
\hline & P29 & $\begin{array}{l}\text { Pengetahuan tentang } \\
\text { manajemen biaya }\end{array}$ & 0.89 \\
\hline & P32 & $\begin{array}{l}\text { Pengetahuan tentang } \\
\text { motivator dan integrator } \\
\text { bagi orang lain }\end{array}$ & 0.869 \\
\hline \multirow{5}{*}{5} & $\mathrm{P} 4$ & $\begin{array}{l}\text { Pendidikan non formal } \\
\text { teknik sipil: Pendidikan } \\
\text { Latihan Manajer Proyek }\end{array}$ & 0.74 \\
\hline & $\mathrm{P} 7$ & Disiplin bekerja & 0.622 \\
\hline & P8 & $\begin{array}{l}\text { Bertanggungjawab } \\
\text { menyelesaikan pekerjaan }\end{array}$ & 0.551 \\
\hline & P19 & $\begin{array}{l}\text { Pernah bekerja di proyek } \\
\text { konstruksi di luar negeri }\end{array}$ & 0.646 \\
\hline & $\mathrm{P} 23$ & $\begin{array}{l}\text { Pernah bekerja } \\
\text { dibeberapa proyek dalam } \\
\text { waktu yang bersamaan }\end{array}$ & 0.5 \\
\hline
\end{tabular}




\begin{tabular}{cclc}
\hline F & $\mathbf{V}$ & $\begin{array}{l}\text { Uraian Kualitas } \\
\text { Manajer Proyek }\end{array}$ & $\mathbf{r}$ \\
\hline & P9 & Mudah beradaptasi & 0.731 \\
\cline { 2 - 4 } & & $\begin{array}{l}\text { Pernah atau masih } \\
\text { memiliki komunitas } \\
\text { dengan sesama profesi } \\
\text { manajer proyek }\end{array}$ & 0.44 \\
\hline 6 & P16 & $\begin{array}{l}\text { Pernah dan masih } \\
\text { menjadi anggota asosiasi } \\
\text { terkait dengan } \\
\text { manajemen proyek }\end{array}$ & 0.774 \\
\hline 7 & P6 & $\begin{array}{l}\text { Berkomunikasi baik } \\
\text { dengan staekholder }\end{array}$ & 0.848 \\
\hline 8 & P15 & $\begin{array}{l}\text { Pernah menjadi manajer } \\
\text { proyek diluar bidang } \\
\text { disiplin ilmu }\end{array}$ & 0.784 \\
\hline
\end{tabular}

Pada tabel diatas menunjukkan 8 faktor baru yang diperoleh pengolahan 37 variabel. Faktorfaktor yang baru yang telah dikelompokkan tersebut diberi identitas yang sesuai dengan variabel-variabel. Adapun identitasnya ialah adalah Pengalaman, Pendidikan, Pengetahuan, Kemampuan, Karakter Diri, Komunikasi, Jaringan Relasi/ Networking, Hubungan Komunikasi, dan Percaya Diri/Performance .

Analisis regresi linier berganda dilakukan terhadap semua faktor yang akan menjadi variabel penentu dalam persamaan regresi. Persamaan regresi bergandanya sebagai berikut:

$\mathrm{Y} 1=0,705+0,45 \cdot \mathrm{X} 1+0,84 \cdot \mathrm{X} 3+0,13 \cdot \mathrm{X} 4$

$\mathrm{Y} 2=0,354+0,13 \cdot \mathrm{X} 3+0,105 \cdot \mathrm{X} 5+0,279 \cdot \mathrm{X} 6$

$\mathrm{Y} 3=(-0,131)+0,05 \cdot \mathrm{X} 2+0,332 \cdot \mathrm{X} 7$

$\mathrm{X} 1=$ Pengalaman

$\mathrm{X} 2=$ Pendidikan

$\mathrm{X} 3=$ Pengetahuan

$\mathrm{X} 4$ = Kemampuan

X5 $=$ Karakter Diri

X6 = Jaringan Relasi

X7 = Hubungan Komunikasi

$\mathrm{X} 8=$ Percaya Diri

$\mathrm{Y} 1=$ Komponen Biaya pelaksanaan proyek

$\mathrm{Y} 2=$ Komponen Waktu pelaksanaan proyek

Y3= Komponen Mutu pelaksanaan proyek

Tabel 2. Pengujian F test

\begin{tabular}{cccc}
\hline $\mathbf{Y}$ & $\mathbf{F o}$ & $\mathbf{F}_{\mathbf{0 , 0 1} \mathbf{( 8 ; 3 6 )}}$ & $\mathbf{F}_{\mathbf{0 , 0 5}(\mathbf{8} ; \mathbf{3 6})}$ \\
\hline Y1 & 4,854 & 2,21 & 3,04 \\
\hline Y2 & 3,414 & 2,21 & 3,04 \\
\hline Y3 & 6,189 & 2,21 & 3,04 \\
\hline
\end{tabular}

Nilai Fo yang diperoleh dari hasil SPSS dan nilai $F$ tabel $\left(\mathrm{F}_{0,05}(8 ; 36)\right)$ untuk significant level $\alpha=0,01$ dan $\alpha=0,05$, derajat kebebasan untuk pembilang $(\mathrm{k})=8$ dan $(\mathrm{n}-1)=36$ didapatkan nilai 2,21 dan 3,04. Pada tabel tersebut menunjukkan bahwa Fo > F tabel baik untuk significant level $\alpha=0,01$ maupun $\alpha=0,05$.

Berdasarkan kriteria pengujian hipotesis, dikatakan menolak hipotesis nol. Hal ini berarti koefisien dari variabel yaitu $\beta_{1}$ dan $\beta_{2} \neq 0$. Dengan demikian telah diketahui besarnya kontribusi bersama daripada semua variabel bebas terhadap variabel terikat. Koefisien korelasi dari perhitungan diatas menyatakan bahwa persamaan regresi linier berganda adalah signifikan, terlihat dari nilai Fo lebih besar dari $\mathrm{F}$ tabel, walaupun diambil $\alpha=0,01$.

Tabel 3. Pengujian $t$ test

\begin{tabular}{cccc}
\hline $\begin{array}{c}\text { Variabel } \\
\text { Terikat }\end{array}$ & $\begin{array}{c}\text { Variabel } \\
\text { Bebas }\end{array}$ & $\begin{array}{c}\text { Nilai B yang } \\
\text { signifikan }\end{array}$ & $\begin{array}{c}\text { Nilai } \\
\mathbf{t}\end{array}$ \\
\hline \multirow{3}{*}{$\mathrm{Y} 1$} & $\mathrm{X} 1$ & $\mathrm{~b} 1$ & 2,093 \\
\cline { 2 - 4 } & $\mathrm{X} 3$ & $\mathrm{~b} 3$ & 2,288 \\
\cline { 2 - 4 } & $\mathrm{X} 4$ & $\mathrm{~b} 4$ & 2,470 \\
\hline \multirow{3}{*}{$\mathrm{Y} 2$} & $\mathrm{X} 3$ & $\mathrm{~b} 3$ & 3,098 \\
\cline { 2 - 4 } & $\mathrm{X} 5$ & $\mathrm{~b} 5$ & 2,421 \\
\cline { 2 - 4 } & $\mathrm{X} 6$ & $\mathrm{~b} 6$ & 2,200 \\
\hline $\mathrm{Y} 3$ & $\mathrm{X} 2$ & $\mathrm{~b} 2$ & 2,676 \\
\cline { 2 - 4 } & $\mathrm{X} 7$ & $\mathrm{~b} 7$ & 2,711 \\
\hline
\end{tabular}

Dengan menggunakan tabel $\mathrm{t}$ dapat diperoleh nilai $\mathrm{t}$ dengan $\mathrm{dk}=(\mathrm{n}-\mathrm{k}-1)=28$, maka tabel $\mathrm{t}=$ 2,048. Nilai $\mathrm{t}$ yang didapat dari hasil SPSS di Coefficients ${ }^{\mathrm{a}}$, dan $\mathrm{t}$ tabel.

Terdapat 3 koefisien regresi yang signifikan untuk persamaan Y1, yaitu b1, b3, b4. Untuk persamaan Y2, yaitu b3,b5,b6 dan untuk persamaan Y3 yaitu b2 dan b7. Sedangkan untuk koefisien regresi selain tersebut pada masing-masing persamaan tidak signifikan.

Tabel 3. Koefisien korelasi

\begin{tabular}{ccc}
\hline $\mathbf{Y}$ & $\mathbf{R}^{2}$ & Sisa \\
\hline $\mathrm{Y} 1$ & $51,9 \%$ & $48,1 \%$ \\
\hline $\mathrm{Y} 2$ & $43,1 \%$ & $56,9 \%$ \\
\hline $\mathrm{Y} 3$ & $57,9 \%$ & $42,1 \%$ \\
\hline
\end{tabular}

Pengujian koefisien korelasi dilakukan untuk mengetahui kontribusi bersama dari seluruh variabel bebas terhadap variabel terikat. Mengingat variabel bebas satu dengan variabel bebas lainnya berkemungkinan besar tidak mandiri, masih memiliki hubungan walaupun kecil, maka kontribusi seluruh variabel bebas terhadap variabel terikat tidak sama dengan jumlah kontribusi masing-masing variabel bebas terhadap variabel terikatnya.

Semua variabel bebas secara bersama mempunyai kontribusi yang signifikan terhadap pembentukan variabel terikat. Nilai $R^{2}$ yang didapat dari penghitungan SPSS pada tabel Model Summary menunjukkan prosentase signifikan dari 
variabel bebas terhadap variabel terikat. Sisa merupakan prosentase yang diakibatkan oleh variabel lain yang tidak diperhitungkan dalam penelitian.

\section{SIMPULAN DAN SARAN}

\section{Simpulan}

Dari penelitian yang sudah dilakukan, dapat disimpulkan sebagai berikut:

1. Penelitian ini menghasilkan 8 (delapan) faktor kualitas manajer proyek yang berpengaruh terhadap pelaksanaan proyek konstruksi Delapan faktor tersebut diperoleh dari hasil pengolahan 37 variabel dari 45 responden dengan menggunakan analisis faktor. Faktor dominan tersebut memiliki nilai eigen values $>1$ yang secara berurutan ialah Pengalaman (41,63\%), Pendidikan $(9,278 \%)$, Pengetahuan $(7,240 \%)$, Kemampuan $(5,088 \%)$, Karakter $(4,047 \%)$, Jaringan $(3,843 \%)$, Hubungan Komunikasi (3,550\%), Percaya Diri $(3,357 \%)$.

Faktor pengalaman memberi indikasi bahwa manajer proyek yang telah menyelesaikan beberapa proyek konstruksi akan sangat berpengaruh pada proyek berikutnya. Segala kesempatan yang diperoleh akan menjadi pelajaran untuk dapat digunakan pada proyek yang baru. Pengalaman selama menjadi staf hingga manajer pada proyek dapat membantu proyek manajer melaksanakan proyek konstruksi menjadi lebih teratur dan terencana.

Faktor pendidikan, pengetahuan dan kemampuan diri, yang rata-rata memiliki prosentase 5\%-10\%, mengindikasikan bahwa wawasan pengetahuan yang luas dapat membantu manajer proyek untuk memberi solusi praktis pada persoalan teknis. Pelatihan maupun latar belakang pendidikan yang tepat dan sesuai dengan kebutuhan proyek, turut mempengaruhi manajer proyek memberi masukan dan arahan pada semua staf pekerja maupun pengelola proyek lainnya. Ditambah pula dengan kemampuan manajer proyek sebagai motivator dan teladan bagi semua tim proyek, akan memberi pengaruh positif bagi semua stakeholder.

Faktor karakter, jaringan, hubungan komunikasi dan percaya diri memiliki prosentase rata-rata dibawah 5\% memberi indikasi bahwa sifat-sifat pribadi seorang manajer proyek turut memberi pengaruh pada pelaksanaan proyek konstruksi. Mulai dari cara menyampaikan tugas, negosiasi, pendelegasian wewenang hingga menegur staf akan berpengaruh bagi stakeholder untuk turut berpartisipasi aktif sesuai arahan manajer proyek.

2. Berdasarkan hasil analisis yang dilakukan dalam penelitian ini, dapat diketahui bahwa analisa kualitas manajer proyek sangat berperan dan berpengaruh terhadap pelaksanaan suatu proyek konstruksi.

Kualitas manajer proyek mempunyai kontribusi yang signifikan terhadap biaya pelaksanaan proyek konstruksi, dengan nilai 51,9\%. Faktor dominan yang berpengaruh adalah faktor pengalaman $(t=2,093)$, faktor pengetahuan $(t=2,288)$ dan faktor kemampuan $(\mathrm{t}=2,470)$. Dengan memiliki latar belakang sebagai proyek manajer, dan wawasan yang terkait dengan anggaran belanja proyek, diyakini seorang manajer proyek dapat menggunakan budget dengan tepat.

Kualitas manajer proyek mempunyai kontribusi terhadap mutu pelaksanaan proyek konstruksi, sebesar 43,1\%. Faktor dominan yang berpengaruh adalah faktor pengetahuan $(t=3,098)$, faktor karakter diri $(\mathrm{t}=2,421)$ dan faktor Jaringan relasi $(\mathrm{t}=2,200)$. Khususnya pengetahuan tentang manajemen kualitas, akan membantu manajer proyek untuk memberi penilaian yang lebih terukur dari suatu material maupun aktivitas. Karakter diri yang disiplin dalam bekerja dan bertanggungjawab menyelesaikan pekerjaan serta adanya ikatan profesi yang terjalin dengan baik turut membantu memberi informasi terbaru terkait aktivitas yang sedang dijalankan, turut memberi pengaruh kuat pada mutu.

Kualitas manajer proyek mempunyai kontribusi yang signifikan terhadap waktu pelaksanaan proyek konstruksi, dengan nilai $57,9 \%$. Faktor dominan yang berpengaruh adalah faktor pendidikan $(\mathrm{t}=2,676)$ dan faktor hubungan komunikasi $(t=2,711)$. Dengan memiliki kemampuan manajemen waktu dan kemampuan berkomunikasi yang baik sesama pengelola proyek, diyakini dapat mengurangi terjadinya keterlambatan pelaksanan proyek.

\section{Saran}

Dengan mengacu pada kesimpulan di atas, saran-saran yang dapat disampaikan adalah sebagai berikut :

1. Untuk dapat menjadi seorang proyek manajer konstruksi yang baik, dibutuhkan pengalaman luas di dunia konstruksi. Pengalaman dari berbagai multi disiplin ilmu akan justru akan meningkatkan kemampuan dalam mengatur, mengarahkan, dan mengendalikan proyek. 
Pendidikan dasar ilmu konstruksi dan manajemen proyek patut dipahami. Karakter pribadi sedapat mungkin bisa menjadi teladan bagi orang lain.

2. Untuk mewujudkan keberhasilan dalam proyek konstruksi dibutuhkan kerjasama yang baik dari manajer proyek dengan semua pihak/ stakeholder yaitu pemilik modal, owner, konsultan, supplier, staf (mandor dan pekerja). Dengan adanya kerjasama yang baik maka pelaksanaan proyek diyakini dapat mencapai keberhasilan secara maksimal baik dari segi biaya, mutu dan waktu.

3. Seorang manajer proyek selayaknya terus meningkatkan kualitas kerjanya dengan meluaskan wawasan baik pergaulan yang luas dan positif, mengikuti seminarseminar yang terkait dengan dunia konstruksi, menambah pengetahuan tentang ilmu pengetahuan dan teknologi agar mengetahui perkembangan dunia konstruksi serta untuk menghadapi persaingan dunia kerja yang semakin ketat.

\section{DAFTAR PUSTAKA}

Adnyana. Swastika, Yana, A. Sudarsana. 2003. Manajemen Proyek Konstruksi Denpasar: Universitas Udayana.

Alwi,S. 2001. Manajemen Sumber Daya Manusia (strategi keunggulan kompetitif) Yogyakarta: FE UGM

Barry, R.B. 2009.Top 10 Qualities of a Project Manager. Available from: URL: http://www/projectsmart.co.uk/top-10qualities-project-manager.html.

Christiawan. 1992. Manajemen Kontraktor. Perpaduan Manajemen dan Budaya. Jakarta: PT. Waskita Karya.

Duncan, W.R. 1996.Project Management Body of Knoledge. USA: Project Management Institute.

Davidson, J. 2002.Manajemen Proyek. Yogyakarta: Andi.

Dipohusodo, I.1996. Manajemen Proyek \& Konstruksi. Yogyakarta: Kanisius.

Emilia, E. 2008. Menulis Tesis dan Disertasi. Bandung: Alfabeta.

Ervianto, W.I. 2003. Manajemen Proyek Konstruksi. Yogyakarta: Andi.

Hadiwiardjo, dkk. 2000. Memasuki Pasar International dengan ISO 9000. Sistem
Manajemen Mutu. Cetakan kedua Jakarta: Ghalia Indonesia.

Husen, A. 2008. Manajemen Proyek. Yogyakarta: Andi.

Hajek, V.G. 1988. Manajemen Proyek Perekayasaan. Edisi Ketiga. Jakarta: Erlangga.

IAMPI, 2000. Standar Nasional Manajemen Proyek Indonesia. Vol. 1 Edisi Pertama. Jakarta.

Kusumawathi, 2004. Pengawasan Masyarakat dalam Mendukung terwujudnya Good Governance (tesis). Denpasar: Universitas Udayana.

Lock, D.1987. Manajemen Proyek. Edisi Ketiga.Jakarta: Erlangga.

Nitisemito A.S. 1996. Manajemen Personalia (manajemen sumber daya manusia). edisi ketiga. Jakarta. Ghalia Indonesia.

Nugraha, P. Natan, I. Sutjipto, R.1986. Manajemen Proyek Konstruksi 2. Surabaya: Kartika Yudha.

Reksohadiprodjo, S. 2001. Manajemen Proyek. edisi kelima. Yogyakarta: BPFE- Yogyakarta.

Siregar, A.B. Samadhi, A.1987. Manajemen. Bandung. Institut Teknologi Bandung.

Soeharto, I. 1995. Manajemen Proyek. Dari Konseptual Sampai Operasional. Jakarta: Erlangga.

Sukaratha, G.S. 2006. Analisis Kinerja Mandor Dalam Menerapkan Manajemen Kualitas Pada Proyek Pembangunan Nusadua Golf Resort Kawasan BTDC-Nusa Dua Bali (tesis). Denpasar: Universitas Udayana.

Surakhmad, W. 1975. Paper Skripsi Thesis Disertasi, cara merencanakan cara menulis cara menilai. Bandung: Tarsito.

Santosa, B. 2003. Manajemen Proyek. edisi pertama cetakan kedua. Surabaya: Guna Widya.

Stoner, J.A.F. dan Wankel, C. 1986. Manajemen, Jakarta: Intermedia.

Wahyudi, E.B. 2002. Organisasi, Prosedur, serta Teknik Penyelenggaraan Suatu Proyek. (prosiding) Manajemen Proyek sebagai Kunci menuju Globalisasi dan Kebangkitan Ekonomi. Lab MK Teknik Sipil FT Unud, Sanur 28 September.

Zacky, M. 2001. Pengaruh Kualitas Manajer Proyek Terhadap Kinerja Waktu Pelaksanaan Proyek Konstruksi bangunan Bertingkat di Jabotabek (tesis). Jakarta: Universitas Indonesia. 